\title{
Bread wheat: a role model for plant domestication and breeding
}

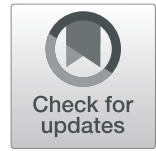

\author{
Eduardo Venske ${ }^{1}$, Railson Schreinert dos Santos ${ }^{1}$, Carlos Busanello ${ }^{1}$, Perry Gustafson ${ }^{2}$ and \\ Antonio Costa de Oliveira ${ }^{1 *}$ (B)
}

\begin{abstract}
Background: Bread wheat is one of the most important crops in the world. Its domestication coincides with the beginning of agriculture and since then, it has been constantly under selection by humans. Its breeding has followed millennia of cultivation, sometimes with unintended selection on adaptive traits, and later by applying intentional but empirical selective pressures. For more than one century, wheat breeding has been based on science, and has been constantly evolving due to on farm agronomy and breeding program improvements. The aim of this work is to briefly review wheat breeding, with emphasis on the current advances.

Discussion: Improving yield potential, resistance/tolerance to biotic and abiotic stresses, and baking quality, have been priorities for breeding this cereal, however, new objectives are arising, such as biofortification enhancement. The narrow genetic diversity and complexity of its genome have hampered the breeding progress and the application of biotechnology. Old approaches, such as the introgression from relative species, mutagenesis, and hybrid breeding are strongly reappearing, motivated by an accumulation of knowledge and new technologies. A revolution has taken place regarding the use of molecular markers whereby thousands of plants can be routinely genotyped for thousands of loci. After 13 years, the wheat reference genome sequence and annotation has finally been completed, and is currently available to the scientific community. Transgenics, an unusual approach for wheat improvement, still represents a potential tool, however it is being replaced by gene editing, whose technology along with genomic selection, speed breeding, and high-throughput phenotyping make up the most recent frontiers for future wheat improvement.
\end{abstract}

Final consideration: Agriculture and plant breeding are constantly evolving, wheat has played a major role in these processes and will continue through decades to come.

Keywords: Hexaploid wheat, Agriculture, Genetic resources, Biotechnology, Genomics

\section{Background}

Bread wheat (Triticum aestivum L.) is one of the most important crop species, responsible for the emergence and development of agriculture and has fed, and continues to feed, a large part of the world's population across many centuries $[97,106]$. Wheat has been improved by man over the last 8000 to 10,000 years ago when the species first arose. Initially it happened in an unconscious way,

\footnotetext{
* Correspondence: acostol@terra.com.br

${ }^{1}$ Plant Genomics and Breeding Center, Crop Science Department, Eliseu Maciel College of Agronomy, Federal University of Pelotas, Capão do Leão Campus, Capão do Leão, Rio Grande do Sul 96010-610, Brazil

Full list of author information is available at the end of the article
}

then intentionally, but empirically, and then, for more than a century, based on scientific knowledge $[18,64]$.

Wheat breeding, as for many other crops, has been evolving fast, both in terms of basic science, methods and tools. The literature on wheat breeding is vast, including countless scientific papers, reviews and even dense book collections already published. Therefore, all relevant aspects and examples cannot be covered in a single text. On the contrary, we do encourage readers to go through this bibliographic ever growing wealth for a deeper understanding on any given topic. Thus, the objective of this review is to provide a brief and valuable synthesis on some selected aspects related to the history, but especially, current advances in wheat breeding, devoted especially to students and researchers with little or

(c) The Author(s). 2019 Open Access This article is distributed under the terms of the Creative Commons Attribution 4.0 International License (http://creativecommons.org/licenses/by/4.0/), which permits unrestricted use, distribution, and 
even no knowledge on the theme. Through this review, the reader can have a quick and general overview on the discussed topics and, when necessary, get a direction to start searching for further literature, as we have tried to cite the most important and recent papers on each topic. Therefore, in the next sections we show the origin of this species and how it became so important with a brief history of wheat cultivation and breeding. Priorities and particularities of wheat breeding are presented. Special consideration is given to new approaches and tools that are currently under development, and the ones that lately reappeared. Finally, the promising future and perspectives are discussed.

\section{Origin and importance}

\section{One of the fathers and lifelong ally of agriculture}

Bread or common wheat is undoubtedly one of the most important cultivated plants, in fact, in addition to its ancestry, the cereal represents a large part of the history of agriculture itself $[8,18,44,58,93,97]$.

Today, wheat is the basis of a significant part of the world's diet, being an important source of energy (providing ca. of $20 \%$ of world population demand), and protein (also providing ca. 20\%), as well as vitamins and other beneficial compounds, not only for humans, but also as animal feed $[42,106]$.

It is grown from $67^{\circ}$ North to $45^{\circ}$ South, including a wide range of altitudes, but it is less cultivated in tropical regions [33]. In 2016, more than 749 million tonnes of this cereal were produced on 220 million hectares around the world, which puts wheat in second place regarding production among the cereal crops (behind maize - Zea mays L.) but in the first position regarding area harvested amongst all crops [32]. Approximately $95 \%$ of wheat cultivated is hexaploid with the remaining $5 \%$ being durum wheat (T. turgidium L.) and few other less important types [106].

\section{The origin of the species}

Bread wheat is an allohexaploid species $(2 n=6 x=42$, AABBDD genomes), resulting from the combination of 3 interrelated diploid genomes [28, 66, 79, 83]. Donors of the A genome ( $T$. urartu) and B genome (closely related to Aegilops speltoides), diverged from a common ancestor about 7 million years ago. These two species first generated $(\sim 5.5$ million years ago $)$ the donor of the $\mathrm{D}$ genome (Ae. tauschii), through hybridization and homoploid speciation. Less than one million years ago emmer wheat ( $T$. turgidum), an allotetraploid with AABB genomes became into existance. Finally, from 8000 to 10,000 years ago, probably in the Fertile Crescent, in a region that nowadays comprises Northern Iran, the hybridization between T. turgidum and Ae. tauschii gave rise to the hexaploid $T$. aestivum, which after domestication and centuries of cultivation and selection, resulted in the bread wheat that is cultivated today $[27,28,53,67,68,79,83,98]$.

Unlike other cultivated species, hexaploid wheat was not selected from a wild species, but arose from the hybridization between a species already cultivated by man that time (emmer wheat), so it is possible to say that maybe there was never any $T$. aestivum in the wild [106]. The reasons why this cereal became so widely adopted by man include its high environmental adaptability, thanks to its allopoliploid nature, which has conferred to wheat the so-called "genomic plasticity". Also, due to its excellent food/feed qualities, not only regarding carbohydrates, proteins and vitamin content, but also for the unique elastic property of its gluten, which provided a more diverse use for its flour $[27,106]$.

\section{The beginning and evolution of wheat cultivation and breeding}

The emergence of modern $T$. aestivum occurred due to agriculture. Thanks to growing its ancestor (emmer) in an area with spontaneous occurrence of Ae. tauschii, the inter-specific hybridization that generated this species occurred [27]. After its emergence, cultivation gradually began to predominate around its center of origin and then expanded to several regions of the globe, improved by natural selection and man in an unintentional way [18].

The "intentional" breeding, even if empirical, began at the end of the XVIII century. The first reported attempts to allow for cross-fertilization of different types of plants was made by Knight (1787) in England. These crosses allowed for the observation of improvements especially for disease resistance [64]. At the end of the XIX century, Vilmorin, in France, and Rimpau in Germany, amongst other breeders, made important contributions in the development of superior wheat genotypes by man-made hybridization or simply selection, motivated by Darwin $[22,23]$, but occurred without a clear understanding of important foundations of their work [64]. Breeding from a solid scientific base began only after the rediscovery of Mendel's findings, at the beginning of the last century. Biffen's classic work [7] was probably the first to validate such knowledge in wheat, once again focusing on disease resistance. Nilsson-Ehle [76] greatly contributed to the study of quantitative traits involving grain color in wheat.

Other advances took place gradually over the decades, until a major leap was made with the so-called "Green Revolution" of the mid-1960s, when wheat and rice (Oryza sativa L.) were protagonists [9, 29, 80, 91]. This revolution consisted in the development of "modern" cultivars - those of wheat mainly by CIMMYT, the International Center for Maize and Wheat Improvement, Mexico. Those were short statured (semi-dwarf), 
photoperiod insensitive and high yielding spring cultivars. This was only possible due to the incorporation of the genes Reduced height (Rht) and Photoperiod (Ppd), which have had extremely important effects on the adaptability of this species. Ppd-D1a, which is an insensitive allele to the photoperiod that reduces flowering time, and $R h t-B 1 b$ and $R h t-D 1 b$, which makes the cereal insensitive to gibberellin, shortened plant's stature. These genes are today widespread in the wheat elite germplasm all around the world and new alleles are still under study, with potential to contribute to this trait $[10,125,128]$.

These new genotypes became widely adopted, especially in developing countries, and generated an impact on the reduction of hunger and poverty, with huge repercussions $[9,29,78,80]$. The Nobel Peace Prize awarded to Dr. Norman E. Borlaug deserves a special mention here, due to his decisive role in this revolution [9].

Since then, wheat breeding has advanced even further with new technologies such as molecular markers, the recent availability of a reference genome sequence and annotation, and even the recent use of techniques such as genome editing, genomic selection, speed breeding and high-throughput phenotyping. The evolution of wheat breeding accross time is briefly illustrated in Fig. 1, highlighting phases and important events.

\section{Wheat breeding: priorities and some general aspects The priorities in wheat breeding}

The main objectives of wheat breeding have been similar over many decades. Increasing the yield potential has been prioritized in order to meet the food requirements of an ever increasing population $[9,80]$.

Probably the second most important trait is disease resistance, as from the first breeding attempts by Knight in 1787 until today, in different countries [64]. For instance, "old diseases", such as the rusts, are still a cause of concern for wheat cultivation, but new ones are appearing, such as wheat blast, considered one of the most recent and concerning threat for wheat cultivation worldwide [127].

Third, is tolerance to abiotic stresses, especially drought and heat - the latter is a borderline to cereal crop expansion, cold and acid soils (aluminum), and various quality traits. Finally, all the others must come, such as resistance to insects, lodging, double-purpose (forage and grain), and improved nutrient use and grain biofortification efficiency, among numerous others. This ranking is based on a general overview on the vast available literature, however this order of priority more than certainly varies within each environmental region and over time.

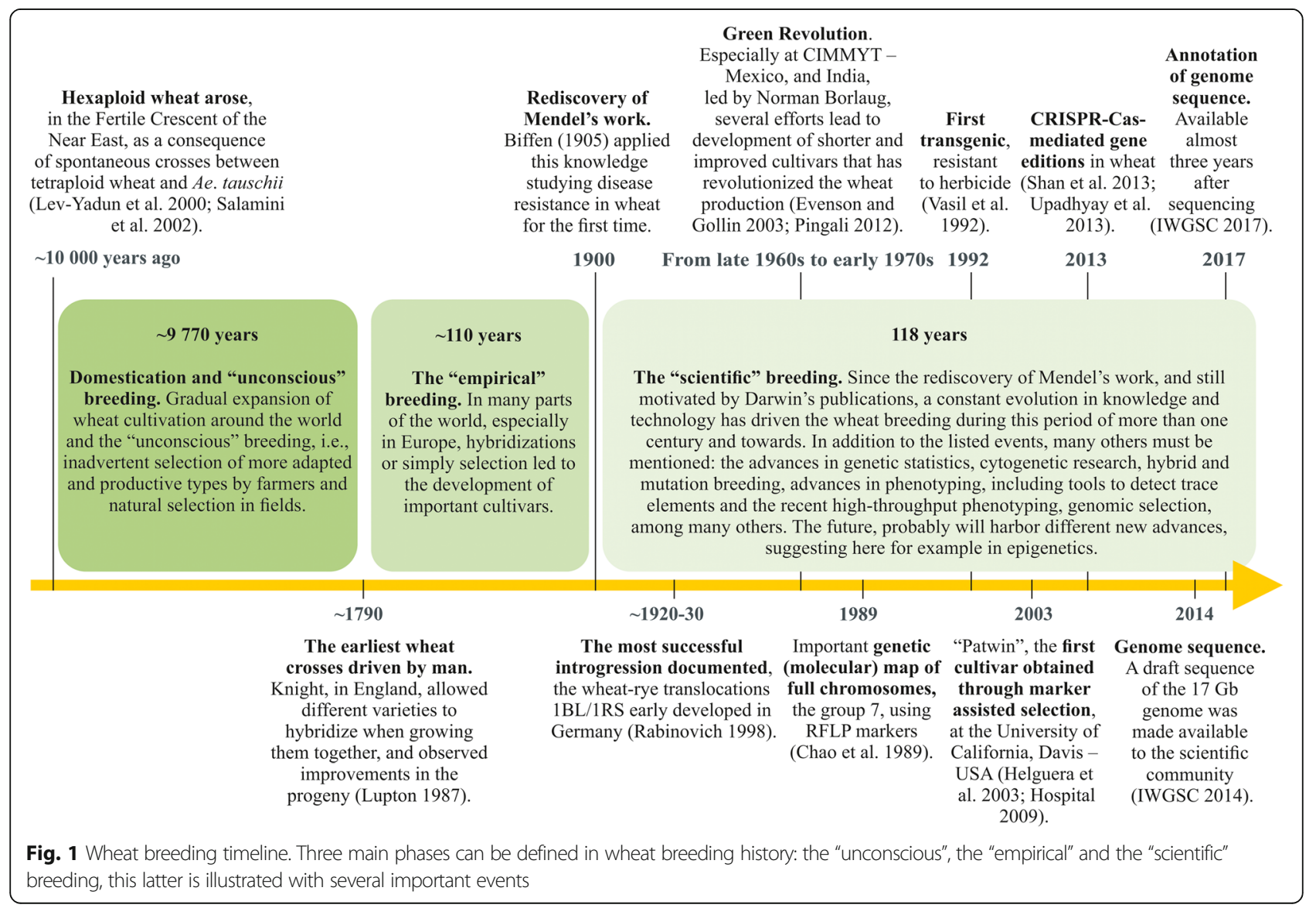


As already mentioned, publications on wheat breeding are vast, fortunately there has been a number of reviews already published, which summarize the most important steps already taken for different traits, ie., yield potential [29, 91], stem rust resistance [107], drought tolerance [74] and biofortification, which should grow in importance over the next few years [129].

\section{New priorities in wheat breeding}

Most future priorities in wheat breeding should remain the same, but the need for faster development and accumulation of knowledge from different fields should provide new strategies and paths to reach these goals. Increasing photosynthetic capacity has been shown to be one of the most important barriers to improve wheat yield potential and there is theoretical evidence that it could be enhanced by the insertion of genes for $\mathrm{C} 4$ carbon fixation, whose strategy has merited investment $[87,90]$.

Wheat grain is known to be rich in gluten, a trait that is critical for baking, but negative for consumption by celiac, and also non-celiac gluten-sensitive people has been a largely discussed topic among nutritionists [15, 37]. This may lead to a potential reduction in wheat consumption in the coming decades, unless we can provide grain that does not possess this disadvantage. Fortunately, there is evidence of some wheats that possess a gluten, but of a chemically different type, which can be consumed by people with celiac disease, potentially becoming an important target for wheat breeding in forthcoming years $[95,111]$.

\section{Special aspects on wheat breeding}

Wheat is a self-pollinated species. Therefore, the conventional structure of its breeding programs do not differ much from other autogamous plants. It includes the use of artificial hybridizations between previously selected genotypes, something already performed for more than two centuries, and different forms of selection within segregating populations $[64,100]$. It is recognized that these processes were, and will continue to be, the main responsiblity for the development of wheat cultivars worldwide. However, new tools and approaches are assisting this process, increasing its success rate and diminishing costs, time and labour.

Improving wheat may be more difficult than for many other crops, since the breeder needs to "match" quantity and quality, allying yield with grain and flour quality, which needs are not a constant concern for crops like soybean (Glycine max L.) or maize (Zea mays L.), which can, for the most part, focus on yield [106]. Also, it is a species with restricted genetic variability when compared to most of other crops. Moreover, its genome size, complexity and polyploid nature constitute a challenge when applying some biotechnological techniques.

\section{The restricted genetic diversity}

Wheat is recognized to have restricted genetic variability, when compared to most other crops $[18,20]$. This is due to several reasons: 1) it is an allohexaploid generated by crosses involving three highly interrelated diploid species, and poplyploidization is a force which restricts itself genetic variability; 2) another reason, suggests that few plants of the ancestral species were involved in the formation of wheat, also restricting its initial genetic variability [27, 58]; 3) Finally, it is a young species, ca. 8000 to 10,000 years old, which is insufficient time for the species to accumulate mutations or to receive genes or alleles by natural or artificial interspecific crossbreeding processes [20, 28, 66].

Domestication, centuries of cultivation, and modern breeding have further restricted the genetic variability of several cultivated species, and wheat is among them [34, $71,89,119]$. It is important to remember that wheat was one of the first species to be domesticated and cultivated, further decreasing its variability due to constant selection cycles since then $[18,58,93]$. The impact of the narrowing of wheat variability is visible through current projections, which show that the cereal might not meet its demand in few decades [88], unless measures are taken in order to broaden its genetic base.

To broaden the genetic diversity available for wheat breeding, different techniques will need to be applied, including induce mutation, genetic transformation, genome editing, and introgressions from species of the secondary and tertiary gene pools.

\section{Resurgent and current approaches in wheat breeding Introgressions}

Among all crop species, wheat is probably the one in which most research has been invested regarding the use of wild and cultivated relatives as source of variability for its improvement. The attempt to incorporate traits of related species into wheat germplasm is not new. In fact, the attempts in this sense began long ago, as early as plant breeding itself [6]. If, on one hand, wheat is restricted in variability within its germplasm, there is an immeasurable richness in variation found in related species belonging to its secondary and tertiary gene pools $[25,102,131]$.

The most important introgression to date in wheat involved a chromosomal translocation $1 R S-1 B L$ between wheat and rye (Secale cereale L.), generated in the first third of the last century, which increased wheat yield potential and resistance/tolerance to biotic and abiotic stresses. This segment is still present in many of important cultivars currently used $[21,85,101]$. The researcher E.R. Sears deserves also a special mention here, due to his great contribution to this field. Today, there are several excellent chromosome manipulation studies in 
progress (e.g. [54]). However, there is a consensus that the practical use of introgressed genes in the development of superior cultivars has in the past been very limited and should be further explored [132].

Another strategy in this field is the development of synthetic wheat, repeating the interspecific crosses that occurred in nature that led to the formation of hexaploid wheat $[61,130]$. In this method, different accessions of the species T. monococcum, T. turgidum, and Ae. tauschii can be used for the formation of new genetic constitutions of wheat, greatly increasing the genetic variability of the primary gene pool [73]. Numerous synthetic wheat germplasm pools have been developed by CIMMYT [130]. This illustrates an advantage that wheat possesses, as an allohexaploid, when compared to diploid species.

The use of other species in wheat pre-breeding programs has been an important field of research (for a complete review, see [72]). Recently, however, it seems to be reaching a new momentum, driven by a remarkable shortage of genetic diversity in wheat, accompanied by an increased need for improved adaptability for the crop. This adaptability is needed to counteract the unfavorable conditions brought by the ongoing climate changes. Enhanced technologies for introgression detection, such as high-throughput genotyping, have motivated investiments in this field. Other potential approaches, such as gene editing will be further discussed in a dedicated section $[12,54,131]$.

\section{Mutagenesis}

Mutation induction, whether via chemical or physical mutagens, has been widely used in order to increase the genetic variability in several cultivated species, including wheat [77]. The polyploid nature of wheat confers a kind of buffer effect, in which mutations in one of its genomes can be compensated by homoeologous genes masking their effect making them difficult to be detected [77]. Fortunately, TILLING methods [108, 114] and high-resolution melting analysis [26] have proven to be efficient for the detection of mutations in the different genomes of hexaploid wheat.

From 1960 to 2017, 256 wheat cultivars were generated by mutagenesis in different countries and have been registered in the FAO/IAEA database (https://mvd.iaea.org). In this repository [31], all cultivars are described with information about how the mutations were induced and focuses on the value-added attributes. Among the many examples of agronomically important mutations are resistance to herbicides of the imidazolinones group [84] and increases in amylose content and starch resistance [109].

\section{Molecular markers and new genotyping approaches}

The use of molecular markers for QTL mapping and marker-assisted selection (MAS), such as for resistance to fusarium head blight [13] and drought [39] has been growing and the accumulation of data generated during the past decades has allowed us to perform different meta-analyses [39]. From the 1990s to 2000s, AFLP, RFLP, and SSR were the most used markers [17, 40, 46, 75, 110]. However, recently a revolution occurred, in which science changed from the use of a few markers, from the types mentioned above, to thousands of single nucleotide polymorphism (SNP) markers using high-throughput platforms. This was initiated with DArT markers [1] and then with SNPs evaluated through genotyping arrays such as Illumina 9 K iSelect Beadchip Assay [16], Illumina ${ }^{\circ}$ iSelect 90 K SNP Assay [121] and Axiom 820 K SNP array [126], in which respectively 9000 to nearly 820,000 SNPs can be evaluated in a single analysis. Also, using genotyping by sequencing (GBS), thanks to the arrival of next generation sequencing technologies, maps containing 20 to $450 \mathrm{~K}$ loci have already been generated for wheat $[82,96]$.

Similarly to other crops, genetic mapping also evolved from mapping populations generated from crosses between only two contrasting parents to genome-wide association studies (GWAS), in which hundreds of diverse accesses are evaluated on each study, thus allowing the capture of a larger genetic diversity and a deeper look in the causal variation between agronomically interesting phenotypes $[3,14,38,56,60,81]$.

\section{Genomic selection}

Although Marker Assisted Selection (MAS) has proven to be useful in a number of situations in wheat breeding, it has the limitation of being only able to aid the selection for a few genes or alleles at a time. However, it is well known in crop breeding that most agronomic traits present a quantitative nature, are governed by numerous genes, most of these with very small effect on the phenotype. In this regard, genomic selection (GS) came as a revolutionizing ally, also in animal breeding [69]. The approach aims ultimately to perform selection and prediction of breeding values based only on genotyping, within a model calibrated with phenotypic values, and with a whole genome perspective, i.e., taking into account genomic polymorphisms in linkage disequilibrium with as many as possible genes with effect on a given trait [51].

The number of studies applying GS in wheat breeding are at an increasing rate. One of the main measures to assay the effectiveness of GS is its accuracy, i.e., how much the prediction compares with the real phenotypes. Applying genotyping by sequencing, GS for wheat yield under irrigated and drought conditions showed accuracies of 0.28 and 0.45 , respectively, which are low to moderate values [81]. On the other hand, GS for fusarium head blight resistance showed moderate to high accuracies, being 0.82 the highest value found, for fusarium damaged kernels trait [4]. High accuracies are 
pursued in this approach, and many factors affect its value, such as the heritability of the trait, the number and quality of the markers, the GS statistical model adopted, among others [43]. In this regard, Bassi et al. [5] proposed different schemes dedicated to the implementation of GS in wheat breeding.

\section{The reference genome sequence and annotation}

In 2005, efforts to generate a reference genome of wheat for the scientific community began, with the establishment of the International Wheat Genome Sequencing Consortium (IWGSC). Nine years latter, in 2014, the first version of this sequence, still considered as a draft, was published for the hexaploid wheat cultivar Chinese Spring [47]. This huge and complex sequence, estimated in 16 to $17 \mathrm{~Gb}$ in total, has been gradually assembled, improved and made available through the repository of the consortium (https://www.wheatgenome.org). Finally, after another 3 years, a first version of the annotation has been made available [48], which has also been continuosly improved [49]. In addition to IWGSC, another research group was responsible for the first nearcomplete assembly of the hexaploid bread wheat genome, with a total of $96 \%$ of its sequence, also of Chinese Spring [136].

Now these reference genomes, especialy the one made available by IWGSC, through its platform for public access, are a powerful tool for breeding and other genetic studies on this crop, being used to better understand wheat evolution $[28,66]$ and for genome wide association studies [3], among many other examples of use.

The completion of the first wheat reference genome of the Chinese Spring cultivar has been considered a stepchange by researchers. However, it is obvious that more representatives from the species should also be sequenced, for a more effective use of genomics in breeding. It motivated the establishment of $10+$ Wheat Genomes Project $\backslash$ (http://www.10wheatgenomes.com/). This global partnership aims to characterize the wheat 'pan genome', and will generate at high quality wheat genome assemblies and develop strategies and resources to compare multiple wheat genome sequences from around the world.

\section{Hybrid breeding}

In some crops, such as maize and rice, the development and cultivation of hybrid cultivars is common, not recent and with clear advantages over the cultivation of open pollinated populations or inbred lines. For wheat, however, less than $1 \%$ of the area is cultivated with hybrids [52, 63]. After unsuccessful attempts during the past decades, research in the development and cultivation of hybrids seems to be becoming one priority in wheat breeding $[63,124]$.
This is due to a huge accumulation of knowledge and new technologies, and recent results are promising. The use of genomic tools to analyze the heterotic pattern among large groups of lines has proved to be efficient in obtaining highly productive hybrids [135], with genome wide selection being the most advantageous method of prediction [60]. In this sense, several hybrids have shown to be highly advantageous regarding yield [62] and resistant to diseases [70], while several difficulties associated with seed production are being overcome [124].

\section{Genetic transformation (transgenics)}

The cultivation of transgenics is still a debate topic in our society. Its acceptance is not unanimous around the world, either because of social or religious reasons [106]. The scientific results have not been able to overcome the fear on its potential effects on human health $[45,65]$. This is why there are not many records of the use of transgenic wheat cultivars [116], not allowing its comparison with crops such as soybean, maize or cotton, even after 27 years of the first transformed wheat [117]. Indeed, authors have termed wheat as the cereal abandoned by GM [127]. Research results, however, have been encouraging, generating genotypes with improved resistance to powdery mildew (Blumeria graminis) [134], leaf spot caused by Bipolaris sorokiniana [50] and fusarium head blight (caused mainly by Fusarium graminearum) [59]. Also, tolerance to drought [118], salinity and freezing [35] and even improvement in baking traits [86] have been achieved, among other traits [116]. Another alternative tool is the creation of cisgenic plants, where transferred genes come from the same species, something that has proven to be more easily accepted by society [113]. Despite these considerations, genetic transformation has been quickly replaced by genome editing, a very powefull approach, as presented in the next topic.

\section{Genome editing}

Among the most recent and promising innovations in terms of biotechnology and plant breeding involves genome or gene editing [11, 99]. This technique can accurately target segments of the genome for modification, either by deletion, insertion or substitution of nucleotides [99]. In wheat, despite the great complexity of its extensive, redundant, and polyploid genome, several attempts have proven to be successful $[105,115,122,133]$. Even a specific protocol for this species has already been established using the CRISPR/Cas9 system [104]. Among the most exciting results obtained with this technique is the simultaneous modification of three homoeo-alleles of the same gene, i.e., being capable of modifying this gene in all three different genomes, demonstrating the precision that these methods have been able to reach [122]. 
Gene editing can also be applied as a tool for gene introgression from wild relatives into wheat background, in which the linkage drag can be mitigated by precise gene replacement [120].

\section{Meiotic recombination manipulation}

Crop breeding relies largely on meiotic recombination, which allows for recombination of genes/alleles in different new genetic compositions, thus allowing selecting new improved cultivars [57]. Controlling this process would be of high interest for breeders. In bread wheat, the Ph1 locus is a well-characterized regulator of this process, whose main role is allowing only homologous chromosomes (belonging to the same genome) to pair and recombine during meiosis $[57,94,103]$. In this regard, there are mutant lines that harbor an alternative allele for this locus, for instance ph1, which is not functional, thus allowing homoeologous chromosomes to pair and recombine [132]. These homoeologous chromosomes include the ones from wheat, but also chromosomes from species from the secondary and tertiary gene pools of the cereal, during the process of gene introgression, being this a powerfull mechanism for this approach [132]. Since other genes appear to contribuite on this mechanism, other studies are being carried out to better elucidate it.

\section{Speed breeding}

Crop breeding is, or, has been, a process which requires considerable time, usualy several years - as for wheat - until a new improved cultivar can be released. The current increasing demand for food added to a number of other factors, such as the ongoing climate change, put pressure on breeding to accelerate the process. Growing segregating lines out of season, at different locations, and the double haploid method have contribuited in this regard, but speed breeding has come as a game-changer to accelerate the plant improvement. It is a very recent approach which ultimately aims to shorten plant's generation time, accelerating breeding and research programmes, in which wheat has been protagonist, among few other crops [123]. It is basically based on photoperiod, light and temperature manipulation (artificially), in growth chambers and glasshouses, and allows one to achieve up to six generations per year - from seed to seed, for spring wheat $[36,123]$. The method not only allows for generation advancing, but also for faster phenotyping for numerous traits, such as flowering time, plant height and disease resistance in wheat [36].

\section{High-throughput phenotyping}

The use of high-throughput phenotyping, aims to evaluate several traits in a large number of plants over a short period of time. This technique is comprised of several highly optimized and automated steps, and emerged also in an attempt to follow the performance achieved through genotyping towards the increasing demands of breeding [2, $14,24]$.

This can be done under controlled conditions, such as in growth chambers or greenhouses, using plant-manipulating robots and photographic cameras with temperature sensors, $\mathrm{CO}_{2}$ meters and scales for weighing live plants [30, 92]. At field level, tractor-coupled or self-propelled platforms, drones or even satellite imagery can perform the tasks $[19,41,55,112]$. After data collection, analysis is also differentiated, requiring specific software, such as for image processing $[30,55]$.

\section{Final considerations and future perspectives}

Agriculture has the challenge of meeting the increasing demand for food by an ever growing world population, and these days in an adverse scenario of climate change, restricted availability of arable land and water and constant evolution of pathogens, among other obstacles. Moreover, the demand for food goes beyond quantity, as quality is also required, especially regarding nutritional aspects. Bread wheat and plant breeding have a crucial role on this task.

Breeding has been responsible for increasing wheat yields and improving many other traits, such grain quality, resistance to biotic stresses, etc. However, the cereal mean genetic gain has to be doubled in the next few decades, in order to meet its global demand. Thus, efforts in the development and implementation of improved strategies must continuously take place in wheat breeding programs.

Classical breeding, which is largelly based on crosses and phenotypic selection has been the most used plant breeding method around the globe for more than one century and is still the main approach these days, responsible for the release of the largest number of cultivars. This approach will still be applied as the main or even unique strategy for several years to come, specially in developing countries. It will be gradually replaced to a certain extent by improved methods, again firstly in developed countries, next, in developing ones. Crosses may be replaced by direct insertion of a gene of interest through gene editing and phenotypic selection by GS. However, the complete extinction of the classical breeding cannot be even conceived. Instead, combined approaches will probably predominate in breeding programs. Crosses followed by speed breeding practices and high-throughput phenotyping for selection or GS is a simple example of a combined scheme.

Gene editing and GS are the current cutting-edge approaches in plant breeding. Both can still be improved to deliver more effective results, which will probably happen within the next decade. However, the most important "improvement" required from these methods resides on the reduction of their costs, which is especially true for GS, as genotyping is still considerably expensive. As science and technology continue to move towards., it is difficult to even 
predict which advance will become available for breeders in two or three decades.

Plant breeding has experienced innovations and revolutions throughout its existence and wheat has been witness to most, if not all, of these transformations and probably will continue as an ally of the transformations to come.

\begin{abstract}
Abbreviations
AFLP: Amplified Fragment Length Polymorphism; CIMMYT: Centro Internacional de Mejoramiento de Maíz Y Trigo (International Center for Maize and Wheat Improvement); CRISPR/Cas9: Clustered Regularly Interspaced Short Palindromic Repeats / CRISPR-associated protein 9; DArT: Diversity Arrays Technology; FAO/ IAEA: Joint: Food and Agriculture Organization of the United Nations / International Atomic Energy Agency; GM: Genetically modified; GS: Genomic Selection; Ph1: Pairing homoeologous 1 (gene); Ppd: Photoperiod (gene); QTL: Quantitative Trait Loci; RFLP: Restriction Fragment Length Polymorphism; Rht: Reduced height (gene); SNP: Single Nucleotide Polymorphism; SSR: Simple Sequence Repeats; TILLING: Targeting Induced Local Lesions IN Genomes
\end{abstract}

\section{Acknowledgements}

We would like to thank the Brazilian funding agencies: Conselho Nacional de Desenvolvimento Científico e Tecnológico (CNPq), Coordenação de Aperfeiçoamento de Pessoal de Nivel Superior (CAPES) and Fundação de Amparo à Pesquisa do Estado do Rio Grande do Sul (FAPERGS).

\section{Authors' contributions}

$\mathrm{ACO}$ and EV contributed for the conception and design of the review; EV wrote the first draft of the manuscript; $A C O, R S S, C B$ and PG performed revisions and wrote parts of the manuscript; $A C O$ performed the final revision of the manuscript. All authors contributed to manuscript revision, read and approved the submitted version.

\section{Funding}

Grants and fellowships were received from the Brazilian Institutes: Conselho Nacional de Desenvolvimento Científico e Tecnológico - CNPq, Coordenação de Aperfeiçoamento de Pessoal de Nível Superior - CAPES and Fundação de Amparo à Pesquisa do Estado do Rio Grande do Sul - FAPERGS.

\section{Availability of data and materials}

Data sharing is not applicable to this article as no datasets were generated or analysed during the current study.

\section{Ethics approval and consent to participate}

Not applicable. The experiments described in this manuscript do not involve human participants.

\section{Consent for publication}

All the authors involved in this study declared their consent to publish the manuscript.

\section{Competing interests}

The authors declare that they have no competing interests.

\section{Author details}

${ }^{1}$ Plant Genomics and Breeding Center, Crop Science Department, Eliseu Maciel College of Agronomy, Federal University of Pelotas, Capão do Leão Campus, Capão do Leão, Rio Grande do Sul 96010-610, Brazil. ${ }^{2}$ Plant Sciences Division, 1-32 Agriculture, University of Missouri, Columbia, MO 65211, USA.

Received: 13 December 2018 Accepted: 20 May 2019

Published online: 29 May 2019

\section{References}

1. Akbari M, Wenzl P, Caig V, et al. Diversity arrays technology (DArT) for highthroughput profiling of the hexaploid wheat genome. Theor Appl Genet. 2006;113:1409-20 https://doi.org/10.1007/s00122-006-0365-4.

2. Araus JL, Cairns JE. Field high-throughput phenotyping: the new crop breeding frontier. Trends Plant Sci. 2014;19:52-61 https://doi.org/10.1016/j. tplants.2013.09.008.
3. Arruda MP, Brown P, Brown-Guedira G, et al. Genome-wide association mapping of Fusarium head blight resistance in Wheat using genotyping-bysequencing. Plant Genome. 2016;9:0 https://doi.org/10.3835/ plantgenome2015.04.0028.

4. Arruda MP, Brown PJ, Lipka AE, et al. Genomic selection for predicting Fusarium head blight resistance in a wheat breeding program. The Plant Genome. 2015;8(3) https://doi.org/10.3835/plantgenome2015.01.0003.

5. Bassi FM, Bentley AR, Charmet G, et al. Breeding schemes for the implementation of genomic selection in wheat (Triticum spp.). Plant Sci. 2016;242:23-36 https://doi.org/10.1016/j.plantsci.2015.08.021.

6. Bedo Z, Láng L. Wheat Breeding: Current status and bottlenecks. In: Molnar M, Ceoloni C, Doležel J (org) alien introgression in Wheat: cytogenetics, molecular biology, and genomics, 1st edn. Springer International Publishing; 2015, p. 203-262.

7. Biffen RH. Mendel's Laws of inheritance and Wheat Breeding. J Agric Sci. 1905;1:4 https://doi.org/10.1017/S0021859600000137.

8. Bilgic H, Hakki EE, Pandey A, et al. Ancient DNA from 8400 year-old Çatalhöyük Wheat: implications for the origin of Neolithic agriculture. PLoS One. 2016;11:e0151974 https://doi.org/10.1371/ journal.pone.0151974.

9. Borlaug NE. Sixty-two years of fighting hunger: personal recollections. Euphytica. 2007;157:287-97 https://doi.org/10.1007/s10681-007-9480-9.

10. Borojevic K, Borojevic K. The transfer and history of "reduced height genes" (Rht) in Wheat from Japan to Europe. J Hered. 2005;96:455-9 https://doi.org/10.1093/jhered/esi060.

11. Bortesi L, Fischer R. The CRISPR/Cas9 system for plant genome editing and beyond. Biotechnol Adv. 2015;33:41-52 https://doi.org/10.1016/j.biotechadv.2014.12.006.

12. Brozynska M, Furtado A, Henry RJ. Genomics of crop wild relatives: expanding the gene pool for crop improvement. Plant Biotechnol J. 2016; 14:1070-85 https://doi.org/10.1111/pbi.12454.

13. Buerstmayr H, Ban T, Anderson JA. QTL mapping and marker-assisted selection for Fusarium head blight resistance in wheat: a review. Plant Breed. 2009;128:1-26 https://doi.org/10.1111/j.1439-0523.2008.01550.x.

14. Cabrera-Bosquet L, Crossa J, von Zitzewitz J, et al. High-throughput phenotyping and genomic selection: the Frontiers of crop Breeding converge. J Integr Plant Biol. 2012;54:312-20 https://doi.org/10.1111/j.17447909.2012.01116.x

15. Catassi C, Bai J, Bonaz B, et al. Non-celiac gluten sensitivity: the new frontier of gluten related disorders. Nutrients. 2013;5:3839-53 https://doi.org/10. 3390/nu5103839.

16. Cavanagh CR, Chao S, Wang S, et al. Genome-wide comparative diversity uncovers multiple targets of selection for improvement in hexaploid wheat landraces and cultivars. Proc Natl Acad Sci. 2013;110:8057-62 https://doi. org/10.1073/pnas.1217133110.

17. Chao S, Sharp PJ, Worland AJ, Warham EJ, Koebner RMD, Gale MD. RFLPbased genetic maps of wheat homoeologous group 7 chromosomes. Theor Appl Genet. 1989;78(4):495-504 https://doi.org/10.1007/BF00290833.

18. Charmet G. Wheat domestication: lessons for the future. C R Biol. 2011;334: 212-20 https://doi.org/10.1016/j.crvi.2010.12.013.

19. Comar A, Burger $P$, de Solan B, et al. A semi-automatic system for high throughput phenotyping wheat cultivars in-field conditions: description and first results. Funct Plant Biol. 2012;39:914 https://doi.org/10.1071/FP12065.

20. Cox TS. Deepening the Wheat Gene Pool. J Crop Prod. 1997;1:1-25 https:// doi.org/10.1300/J144v01n01_01.

21. Crespo-Herrera L, Garkava-Gustavsson L, Åhman I. A systematic review of rye (Secale cereale L.) as a source of resistance to pathogens and pests in wheat (Triticum aestivum L.). Hereditas. 2017;154(14) https://doi.org/10.1186/ s41065-017-0033-5.

22. Darwin CR. On the origin of species by means of natural selection, or the preservation of favoured races in the struggle for life. London; 1859.

23. Darwin CR. The variation of animals and plants under domestication. London; 1868.

24. de Souza N. High-throughput phenotyping. Nat Methods. 2010;7:36 https:// doi.org/10.1038/nmeth.f.289.

25. Dempewolf $\mathrm{H}$, Baute $\mathrm{G}$, Anderson J, et al. Past and future use of wild relatives in crop Breeding. Crop Sci. 2017;57:1070-82 https://doi.org/10. 2135/cropsci2016.10.0885.

26. Dong C, Vincent K, Sharp P. Simultaneous mutation detection of three homoeologous genes in wheat by high resolution melting analysis and mutation surveyor ${ }^{\circledast}$. BMC Plant Biol. 2009;9:143 https://doi.org/10.1186/14712229-9-143 
27. Dubcovsky J, Dvorak J. Genome plasticity a key factor in the success of Polyploid Wheat under domestication. Science. 2007;316:1862-6 https://doi. org/10.1126/science.1143986.

28. El Baidouri $M$, Murat $F$, Veyssiere $M$, et al. Reconciling the evolutionary origin of bread wheat (Triticum aestivum). New Phytol. 2017;213:1477-86 https://doi.org/10.1111/nph.14113.

29. Evenson RE, Gollin D. Assessing the impact of the Green revolution, 1960 to 2000. Science. 2003;300:758-62 https://doi.org/10.1126/science.1078710.

30. Fahlgren N, Gehan MA, Baxter I. Lights, camera, action: high-throughput plant phenotyping is ready for a close-up. Curr Opin Plant Biol. 2015;24:93-9 https://doi.org/10.1016/j.pbi.2015.02.006.

31. FAO/IAEA. Mutant Variety Database. 2017. https://mvd.iaea.org/. Accessed 6 Oct 2017.

32. FAOSTAT - Statistical databases. Food and Agriculture Organization of the United Nations. 2018. http://www.fao.org/faostat/en/\#home. Accessed 24 Nov 2018

33. Feldman M. Wheats. In: Smartt J, Simmonds NW. (orgs) evolution of crop plants. Longman scientific and technical. Harlow; 1995. p. 185-192.

34. Fu Y-B, Somers DJ. Genome-wide reduction of genetic diversity in Wheat Breeding. Crop Sci. 2009;49:161-8 https://doi.org/10.2135/cropsci2008.03.0125.

35. Gao S-Q, Chen M, Xia L-Q, et al. A cotton (Gossypium hirsutum) DRE-binding transcription factor gene, GhDREB, confers enhanced tolerance to drought, high salt, and freezing stresses in transgenic wheat. Plant Cell Rep. 2009;28:301-11 https://doi.org/10.1007/s00299-008-0623-9.

36. Gosh S, Watson A, Gonzalez-Navarro OE, et al. Speed breeding in growth chambers and glasshouses for crop breeding and model plant research. Nat Protoc. 2018;13:2944-63 https://doi.org/10.1038/s41596-018-0072-z.

37. Green PHR, Jabri B. Coeliac disease. Lancet. 2003;362:383-91 https://doi.org/ 10.1016/S0140-6736(03)14027-5.

38. Guo Z, Chen D, Alqudah AM, et al. Genome-wide association analyses of 54 traits identified multiple loci for the determination of floret fertility in wheat. New Phytol. 2017;214:257-70 https://doi.org/10.1111/nph.14342.

39. Gupta P, Balyan H, Gahlaut V. QTL analysis for drought tolerance in Wheat: present status and future possibilities. Agronomy. 2017;7:5 https:/doi.org/ 10.3390/agronomy7010005.

40. Gupta PK, Langridge P, Mir RR. Marker-assisted wheat breeding: present status and future possibilities. Mol Breed. 2010;26:145-61 https://doi.org/10. 1007/s11032-009-9359-7.

41. Haghighattalab A, González Pérez L, Mondal S, et al. Application of unmanned aerial systems for high throughput phenotyping of large wheat breeding nurseries. Plant Methods. 2016;12(35) https://doi.org/10.1186/ s13007-016-0134-6.

42. Hawkesford MJ, Araus J-L, Park R, et al. Prospects of doubling global wheat yields. Food Energy Secur. 2013;2:34-48 https://doi.org/10.1002/fes3.15.

43. Heffner EL, Sorrells ME, Jannink J-L. Genomic selection for crop improvement. Crop Sci. 2009;49(1):12 https://doi.org/10.2135/cropsci2008.08.0512.

44. Heun M, Schäfer-Pregl R, Klawan D, et al. Site of einkorn Wheat domestication identified by DNA fingerprinting. Science. 1997;278:1312-4 https://doi.org/10.1126/science.278.5341.1312

45. Hilbeck A, Binimelis R, Defarge N, et al. No scientific consensus on GMO safety. Environ Sci Eur. 2015;27:4 https://doi.org/10.1186/s12302-014-0034-1.

46. Hospital F. Challenges for effective marker-assisted selection in plants. Genetica. 2009:136:303-10 https://doi.org/10.1007/s10709-008-9307-1.

47. International Wheat Genome Sequencing Consortium. A chromosome-based draft sequence of the hexaploid bread wheat (Triticum aestivum) genome. Science. 2014;345(6194):1251788 https://doi.org/10.1126/science.1251788.

48. International Wheat Genome Sequencing Consortium. Generating a high quality genome sequence of bread wheat. 2018a. https://www.wheatgenome.org/. Accessed 09 May 2018.

49. International Wheat Genome Sequencing Consortium. Shifting the limits in wheat research and breeding using a fully annotated reference genome. Science. 2018b;361(6403):7191 https://doi.org/10.1126/science.aar7191.

50. Janni M, Sella L, Favaron F, et al. The expression of a bean PGIP in transgenic Wheat confers increased resistance to the fungal pathogen Bipolaris sorokiniana. Mol PlantMicrobe Interact. 2008;21:171-7 https://doi.org/10.1094/MPMI-21-2-0171.

51. Jannink J-L, Lorenz AJ, Iwata H. Genomic selection in plant breeding: from theory to practice. Brief Funct Genomics. 2010;9:166-77 https://doi.org/10. 1093/bfgp/elq001.

52. Kempe K, Rubtsova M, Gils M. Split-gene system for hybrid wheat seed production. Proc Natl Acad Sci. 2014;111:9097-102 https://doi.org/10.1073/ pnas. 1402836111.
53. Kihara $\mathrm{H}$. Discovery of the DD-analyser, one of the ancestors of vulgare wheat. Agric Hortic. 1944;19:889-90.

54. King J, Grewal S, Yang C, et al. A step change in the transfer of interspecific variation into wheat from Amblyopyrum muticum. Plant Biotechnol J. 2017; 15:217-26 https://doi.org/10.1111/pbi.12606.

55. Kipp S, Mistele B, Baresel P, Schmidhalter U. High-throughput phenotyping early plant vigour of winter wheat. Eur J Agron. 2014;52:271-8 https://doi. org/10.1016/j.eja.2013.08.009.

56. Kollers S, Rodemann B, Ling J, et al. Whole genome association mapping of Fusarium head blight resistance in European winter Wheat (Triticum aestivum L.). PLoS One. 2013;8:e57500 https://doi.org/10.1371/journal.pone. 0057500 .

57. Lawrence EJ, Griffin CH, Henderson IR. Modification of meiotic recombination by natural variation in plants. J Exp Bot. 2017;68:5471-83 https://doi.org/10.1093/jxb/erx306.

58. Lev-Yadun S, Gopher A, Abbo S. The cradle of agriculture. Science. 2000;288: 1602-3 https://doi.org/10.1126/science.288.5471.1602.

59. Li X, Shin S, Heinen S, et al. Transgenic Wheat expressing a barley UDPglucosyltransferase detoxifies Deoxynivalenol and provides high levels of resistance to Fusarium graminearum. Mol Plant-Microbe Interact. 2015;28: 1237-46 https://doi.org/10.1094/MPMI-03-15-0062-R.

60. Liu G, Zhao Y, Gowda M, et al. Predicting hybrid performances for quality traits through genomic-assisted approaches in central European Wheat. PLoS One. 2016;11:e0158635 https://doi.org/10.1371/journal.pone.0158635.

61. Liu S, Zhou R, Dong Y, et al. Development, utilization of introgression lines using a synthetic wheat as donor. Theor Appl Genet. 2006;112:1360-73 https://doi.org/10.1007/s00122-006-0238-X.

62. Longin CFH, Gowda M, Mühleisen J, et al. Hybrid wheat: quantitative genetic parameters and consequences for the design of breeding programs. Theor Appl Genet. 2013;126:2791-801 https://doi.org/10.1007/ s00122-013-2172-z.

63. Longin CFH, Mühleisen J, Maurer HP, et al. Hybrid breeding in autogamous cereals. Theor Appl Genet. 2012;125:1087-96 https://doi.org/10.1007/s00122012-1967-7.

64. Lupton FGH. Wheat Breeding. Dordrecht: Springer Netherlands; 1987.

65. Lynas M. Rothamsted's aphid-resistant wheat - a turning point for GMOs? Agric Food Secur. 2012;1(17) https://doi.org/10.1186/2048-7010-1-17.

66. Marcussen T, Sandve SR, Heier L, et al. Ancient hybridizations among the ancestral genomes of bread wheat. Science. 2014;345:1250092 https://doi. org/10.1126/science.1250092.

67. Mayer KFX, Rogers J, Dole el J, et al. A chromosome-based draft sequence of the hexaploid bread wheat (Triticum aestivum) genome. Science. 2014; 345:1251788 https://doi.org/10.1126/science.1251788.

68. McFadden ES, Sears ER. The origin of Triticum spelta and its free-threshing hexaploid relatives. J Hered. 1946;37:107-16 https://doi.org/10.1093/ oxfordjournals.jhered.a105590.

69. Meuwissen THE, Hayes BJ, Goddard ME. Prediction of total genetic value using genome-wide dense marker maps. Genetics. 2001;157:1819-29.

70. Miedaner T, Schulthess AW, Gowda M, et al. High accuracy of predicting hybrid performance of Fusarium head blight resistance by mid-parent values in wheat. Theor Appl Genet. 2017;130:461-70 https://doi.org/10.1007/ s00122-016-2826-8.

71. Mir RR, Kumar J, Balyan HS, Gupta PK. Study of genetic diversity among Indian bread wheat (Triticum aestivum L.) cultivars released during last 100 years. Genet Resour Crop Evol. 2012;59:717 https://doi.org/10.1007/s10722011-9713-6.

72. Molnár-Láng M, Ceoloni C, Doležel J. Alien introgression in Wheat: cytogenetics, molecular biology, and genomics, 1st edn: Springer International Publishing; 2015.

73. Mujeeb-Kazi A, Gul A, Farooq M, et al. Rebirth of synthetic hexaploids with global implications for wheat improvement. Aust J Agric Res. 2008:59:391 https://doi.org/10.1071/AR07226.

74. Mwadzingeni L, Shimelis $H$, Dube $E$, et al. Breeding wheat for drought tolerance: Progress and technologies. J Integr Agric. 2016;15:935-43 https:// doi.org/10.1016/S2095-3119(15)61102-9.

75. Nagaoka T, Ogihara Y. Applicability of inter-simple sequence repeat polymorphisms in wheat for use as DNA markers in comparison to RFLP and RAPD markers. Theor Appl Genet. 1997;94:597-602 https://doi.org/10. 1007/s001220050456.

76. Nilsson-Ehle H. Arbetena med hvete och havre vid Svalof under ar 1909. Sv Utsädesf Tidskr. 1910;20:332-53. 
77. Parry MAJ, Madgwick PJ, Bayon C, et al. Mutation discovery for crop improvement. J Exp Bot. 2009;60:2817-25 https://doi.org/10.1093/jxb/erp189.

78. Peng J, Richards DE, Hartley NM, et al. "Green revolution" genes encode mutant gibberellin response modulators. Nature. 1999;400:256-61 https:// doi.org/10.1038/22307.

79. Petersen G, Seberg O, Yde M, Berthelsen K. Phylogenetic relationships of Triticum and Aegilops and evidence for the origin of the $\mathrm{a}, \mathrm{B}$, and D genomes of common wheat (Triticum aestivum). Mol Phylogenet Evol. 2006; 39:70-82 https://doi.org/10.1016/j.ympev.2006.01.023.

80. Pingali PL. Green revolution: impacts, limits, and the path ahead. Proc Natl Acad Sci. 2012;109:12302-8 https://doi.org/10.1073/pnas.0912953109.

81. Poland J, Endelman J, Dawson J, et al. Genomic selection in Wheat Breeding using genotyping-by-sequencing. Plant Genome J. 2012b;5:103 https://doi.org/10.3835/plantgenome2012.06.0006.

82. Poland JA, Brown PJ, Sorrells ME, Jannink J-L. Development of high-density genetic maps for barley and Wheat using a novel two-enzyme genotypingby-sequencing approach. PLoS One. 2012a;7:e32253 https://doi.org/10.1371/ journal.pone.0032253.

83. Pont C, Salse J. Wheat paleohistory created asymmetrical genomic evolution Curr Opin Plant Biol. 2017;36:29-37 https:/doi.org/10.1016/j.pbi.2017.01.001.

84. Pozniak CJ, Hucl PJ. Genetic analysis of Imidazolinone resistance in mutation-derived lines of common Wheat. Crop Sci. 2004;44:23 https://doi. org/10.2135/cropsci2004.2300.

85. Rabinovich SV. Importance of wheat-rye translocations for breeding modern cultivar of Triticum aestivum L. Euphytica. 1998;100:323-40 https://doi.org/ 10.1023/A:1018361819215.

86. Rakszegi M, Békés F, Láng $L$, et al. Technological quality of transgenic wheat expressing an increased amount of a HMW glutenin subunit. J Cereal Sci. 2005;42:15-23 https://doi.org/10.1016/j.jcs.2005.02.006.

87. Rangan P, Furtado A, Henry RJ. New evidence for grain specific C4 photosynthesis in wheat. Sci Rep. 2016;6:31721 https:/doi.org/10.1038/srep31721.

88. Ray DK, Mueller ND, West PC, et al. Yield trends are insufficient to double global crop production by 2050. PLoS One. 2013;8:e66428 https://doi.org/ 10.1371/journal.pone.0066428.

89. Reif JC, Zhang P, Dreisigacker S, et al. Wheat genetic diversity trends during domestication and breeding. Theor Appl Genet. 2005;110:859-64 https:// doi.org/10.1007/s00122-004-1881-8.

90. Reynolds M, Bonnett D, Chapman SC, et al. Raising yield potential of wheat. I. Overview of a consortium approach and breeding strategies. J Exp Bot. 2011;62:439-52 https://doi.org/10.1093/jxb/erq311.

91. Reynolds MP, Borlaug NE. Impacts of breeding on international collaborative wheat improvement. J Agric Sci. 2006;144:3 https://doi.org/10.1017/ S0021859606005867.

92. Richard C, Hickey LT, Fletcher S, et al. High-throughput phenotyping of seminal root traits in wheat. Plant Methods. 2015;11:13 https://doi.org/10. 1186/s13007-015-0055-9

93. Riehl S, Zeidi M, Conard NJ. Emergence of agriculture in the foothills of the Zagros Mountains of Iran. Science. 2013;341:65-7 https://doi.org/10.1126/ science.1236743.

94. Riley R, Chapman V. Genetic control of the cytologically diploid behaviour of hexaploid wheat. Nature. 1958;182:713-5https://doi.org/10.1038/182713a0.

95. Rosell CM, Barro F, Sousa C, Mena MC. Cereals for developing gluten-free products and analytical tools for gluten detection. J Cereal Sci. 2014;59:35464 https://doi.org/10.1016/j.jcs.2013.10.001.

96. Saintenac C, Jiang D, Wang S, Akhunov E. Sequence-based mapping of the Polyploid Wheat genome. G3: Genes Genomes Genetics. 2013;3:1105-14 https://doi.org/10.1534/g3.113.005819.

97. Salamini F, Özkan H, Brandolini A, et al. Genetics and geography of wild cereal domestication in the near east. Nat Rev Genet. 2002;3:429-41 https:// doi.org/10.1038/nrg817.

98. Salse J, Chagué $\mathrm{V}$, Bolot $\mathrm{S}$, et al. New insights into the origin of the $\mathrm{B}$ genome of hexaploid wheat: evolutionary relationships at the SPA genomic region with the $\mathrm{S}$ genome of the diploid relative Aegilops speltoides. BMC Genomics. 2008:9:555 https://doi.org/10.1186/1471-2164-9-555.

99. Sander JD, Joung JK. CRISPR-Cas systems for editing, regulating and targeting genomes. Nat Biotechnol. 2014;32:347-55 https://doi.org/10.1038/nbt.2842.

100. Scheeren PL, Caierão E, Silva MS, Bonow S. Melhoramento no Brasil de trigo. In: Trigo no Brasil: Embrapa; 2011. p. 488.

101. Schlegel R, Korzun V. About the origin of 1RS.1BL wheat-rye chromosome translocations from Germany. Plant Breed. 1997;1 16:537-40 https://doi.org/ 10.1111/j.1439-0523.1997.tb02186.x.
102. Schneider A, Molnár I, Molnár-Láng M. Utilisation of Aegilops (goatgrass) species to widen the genetic diversity of cultivated wheat. Euphytica. 2008; 163:1-19 https://doi.org/10.1007/s10681-007-9624-y.

103. Sears ER. An induced mutant with homoeologous pairing in common wheat. Can J Genet Cytol. 1977;19:585-93 https://doi.org/10.1139/g77-063.

104. Shan Q, Wang Y, Li J, Gao C. Genome editing in rice and wheat using the CRISPR/Cas system. Nat Protoc. 2014;9:2395-410 https://doi.org/10.1038/ nprot.2014.157.

105. Shan Q, Wang Y, Li J, et al. Targeted genome modification of crop plants using a CRISPR-Cas system. Nat Biotechnol. 2013;31:686 https://doi.org/10. 1038/nbt.2650.

106. Shewry PR. Wheat. J Exp Bot. 2009;60:1537-53 https://doi.org/10.1093/jxb/ erp058.

107. Singh R. Current status, likely migration and strategies to mitigate the threat to wheat production from race Ug99 (TTKS) of stem rust pathogen. CAB Rev Perspect Agric Vet Sci Nutr Nat Resour 2006;1. https://doi.org/10.1079/ PAVSNNR20061054

108. Slade AJ, Fuerstenberg SI, Loeffler D, et al. A reverse genetic, nontransgenic approach to wheat crop improvement by TILLING. Nat Biotechnol. 2005;23: 75-81 https://doi.org/10.1038/nbt1043.

109. Slade AJ, McGuire C, Loeffler D, et al. Development of high amylose wheat through TILLING. BMC Plant Biol. 2012;12:69 https://doi.org/10.1186/14712229-12-69.

110. Song QJ, Shi JR, Singh S, et al. Development and mapping of microsatellite (SSR) markers in wheat. Theor Appl Genet. 2005;110:550 https://doi.org/10. 1007/s00122-004-1871-x

111. Spaenij-Dekking $L$, Kooy-Winkelaar $Y$, van Veelen $P$, et al. Natural variation in toxicity of Wheat: potential for selection of nontoxic varieties for celiac disease patients. Gastroenterology. 2005;129:797-806 https://doi.org/10. 1053/j.gastro.2005.06.017.

112. Tattaris M, Reynolds MP, Chapman SC. A direct comparison of remote sensing approaches for high-throughput phenotyping in plant Breeding. Front Plant Sci. 2016;7:1-9 https://doi.org/10.3389/fpls.2016.01131.

113. Tester $M$, Langridge $P$. Breeding technologies to increase crop production in a changing world. Science. 2010;327:818-22 https://doi.org/10.1126/ science. 1183700

114. Uauy C, Paraiso F, Colasuonno P, et al. A modified TILLING approach to detect induced mutations in tetraploid and hexaploid wheat. BMC Plant Biol. 2009;9:115 https://doi.org/10.1186/1471-2229-9-115.

115. Upadhyay SK, Kumar J, Alok A, Tuli R. RNA-guided genome editing for target gene mutations in Wheat. G3: Genes Genomes Genetics. 2013;3: 2233-8 https://doi.org/10.1534/g3.113.008847.

116. Vasil IK. Molecular genetic improvement of cereals: transgenic wheat (Triticum aestivum L.). Plant Cell Rep. 2007;26:1133-54 https://doi.org/10. 1007/s00299-007-0338-3.

117. Vasil V, Castillo AM, Fromm ME, Vasil IK. Herbicide resistant fertile transgenic Wheat plants obtained by microprojectile bombardment of regenerable embryogenic callus. Nat Biotechnol. 1992;10:667-74 https://doi.org/10.1038/ nbt0692-667.

118. Vendruscolo ECG, Schuster I, Pileggi M, et al. Stress-induced synthesis of proline confers tolerance to water deficit in transgenic wheat. J Plant Physiol. 2007;164:1367-76 https://doi.org/10.1016/j.jplph.2007.05.001.

119. Voss-Fels K, Frisch M, Qian L, et al. Subgenomic diversity patterns caused by directional selection in bread Wheat gene pools. Plant Genome. 2015;8:0 https://doi.org/10.3835/plantgenome2015.03.0013.

120. Wang M, Wang S, Liang Z, et al. From genetic stock to genome editing: gene exploitation in Wheat. Trends Biotechnol. 2018;36:160-72 https://doi. org/10.1016/j.tibtech.2017.10.002.

121. Wang S, Wong D, Forrest K, et al. Characterization of polyploid wheat genomic diversity using a high-density 90,000 single nucleotide polymorphism array. Plant Biotechnol J. 2014a;12:787-96 https://doi.org/10. 1111/pbi.12183.

122. Wang $Y$, Cheng $X$, Shan $Q$, et al. Simultaneous editing of three homoeoalleles in hexaploid bread wheat confers heritable resistance to powdery mildew. Nat Biotechnol. 2014b;32:947-51 https://doi.org/10.1038/nbt.2969.

123. Watson A, Ghosh S, Williams MJ, et al. Speed breeding is a powerfull tool to accelerate crop research and breeding. Nat Plants. 2018:4:23-9 https://doi. org/10.1038/s41477-017-0083-8.

124. Whitford R, Fleury D, Reif JC, et al. Hybrid breeding in wheat: technologies to improve hybrid wheat seed production. J Exp Bot. 2013:64:5411-28 https://doi.org/10.1093/jxb/ert333. 
125. Wilhelm EP, Boulton Ml. Al-Kaff, et al. Rht-1 and Ppd-D1 associations with height, GA sensitivity, and days to heading in a worldwide bread wheat collection. Theor Appl Genet. 2013;126:2233-43 https://doi.org/10.1007/ s00122-013-2130-9.

126. Winfield MO, Allen AM, Burridge AJ, et al. High-density SNP genotyping array for hexaploid wheat and its secondary and tertiary gene pool. Plant Biotechnol J. 2016;14:1195-206 https://doi.org/10.1111/pbi.12485.

127. Wulff BBH, Dhugga KS. Wheat - the cereal abandoned by GM. Science. 2018; 361:451-2 https://doi.org/10.1126/science.aat5119.

128. Würschum T, Langer SM, Longin CFH, et al. A modern Green revolution gene for reduced height in wheat. Plant J. 2017;92:892-903 https:/doi.org/ 10.1111/tpj.13726.

129. Xu Y, An D, Li H, Xu H. Review: Breeding wheat for enhanced micronutrients. Can J Plant Sci. 2011;91:231-7 https://doi.org/10.4141/ CJPS10117.

130. Yang W, Liu D, Li J, et al. Synthetic hexaploid wheat and its utilization for wheat genetic improvement in China. J Genet Genomics. 2009;36:539-46 https://doi.org/10.1016/S1673-8527(08)60145-9.

131. Zhang H, Mittal N, Leamy LJ, et al. Back into the wild—apply untapped genetic diversity of wild relatives for crop improvement. Evol Appl. 2017a; 10:5-24 https://doi.org/10.1111/eva.12434.

132. Zhang W, Cao Y, Zhang M, et al. Meiotic Homoeologous recombinationbased alien gene introgression in the genomics era of Wheat. Crop Sci. 2017b;57:1189-98 https://doi.org/10.2135/cropsci2016.09.0819.

133. Zhang Y, Liang Z, Zong Y, et al. Efficient and transgene-free genome editing in wheat through transient expression of CRISPR/Cas9 DNA or RNA. Nat Commun. 2016;7(12617) https://doi.org/10.1038/ncomms12617.

134. Zhao T-J, Zhao S-Y, Chen H-M, et al. Transgenic wheat progeny resistant to powdery mildew generated by Agrobacterium inoculum to the basal portion of wheat seedling. Plant Cell Rep. 2006;25:1199-204 https://doi.org/ 10.1007/s00299-006-0184-8

135. Zhao Y, Li Z, Liu G, et al. Genome-based establishment of a high-yielding heterotic pattern for hybrid wheat breeding. Proc Natl Acad Sci. 2015;112: 201514547 https://doi.org/10.1073/pnas.1514547112.

136. Zimin AV, Puiu D, Hall R, Kingan S, Clavijo BJ, Salzberg SL. The first nearcomplete assembly of the hexaploid bread wheat genome, Triticum aestivum. Gigascience. 2017;6(11):gix097. https://doi.org/10.1093/ gigascience/gix097.

\section{Publisher's Note}

Springer Nature remains neutral with regard to jurisdictional claims in published maps and institutional affiliations.

Ready to submit your research? Choose BMC and benefit from:

- fast, convenient online submission

- thorough peer review by experienced researchers in your field

- rapid publication on acceptance

- support for research data, including large and complex data types

- gold Open Access which fosters wider collaboration and increased citations

- maximum visibility for your research: over $100 \mathrm{M}$ website views per year

At $\mathrm{BMC}$, research is always in progress.

Learn more biomedcentral.com/submissions 